\title{
Diversity and vertical distribution of microbial eukaryotes in the snow, sea ice and seawater near the North Pole at the end of the polar night
}

\author{
Charles Bachy' , Purificación López-García' , Alexander Vereshchaka' and David Moreira ${ }^{1 *}$ \\ 1 Unité d'Ecologie, Systématique et Evolution, UMR CNRS 8079, Université Paris-Sud, Orsay, France \\ 2 Institute of Oceanology, Russian Academy of Sciences, Moscow, Russia
}

\section{Edited by:}

Jennifer F. Biddle, University of

Delaware, USA

\section{Reviewed by:}

Peter D. Countway, Bigelow Laboratory for Ocean Sciences, USA

Daniel Vaulot, Station Biologique de

Roscoff, France

${ }^{*}$ Correspondence:

David Moreira, Unité d'Ecologie, Systématique et Evolution, UMR CNRS 8079, Université Paris-Sud, 91405 Orsay Cedex, France. e-mail:david.moreira@u-psud.fr
Our knowledge about the microorganisms living in the high Arctic Ocean is still rudimentary compared to other oceans mostly because of logistical challenges imposed by its inhospitable climate and the presence of a multi-year ice cap. We have used $18 \mathrm{~S}$ rRNA gene libraries to study the diversity of microbial eukaryotes in the upper part of the water column (0-170 m depth), the sea ice (0-1.5 m depth) and the overlying snow from samples collected in the vicinity of the North Pole (N88 $\left.{ }^{\circ} 5^{\prime}, \mathrm{E} 015^{\circ} 59\right)$ at the very end of the long polar night. We detected very diverse eukaryotes belonging to Alveolata, Fungi, Amoebozoa, Viridiplantae, Metazoa, Rhizaria, Heterokonta, and Telonemia. Different alveolates (dinoflagellates and Marine Alveolate Groups I and II species) were the most abundant and diverse in gene libraries from water and sea ice, representing $80 \%$ of the total number of clones and operational taxonomic units. Only contaminants and/or species from continental ecosystems were detected in snow, suggesting wind- and animal- or humanmediated cosmopolitan dispersal of some taxa. By contrast, sea ice and seawater samples harbored a larger and more similar inter-sample protist diversity as compared with snow. The North Pole was found to harbor distinctive eukaryotic communities along the vertical gradient with an unparalleled diversity of core dinoflagellates, largely dominant in libraries from the water column, as compared to other oceanic locations. In contrast, phototrophic organisms typical of Arctic sea ice and plankton, such as diatoms and prasinophytes, were very rare in our samples. This was most likely due to a decrease of their populations after several months of polar night darkness and to the presence of rich populations of diverse grazers. Whereas strict phototrophs were scarce, we identified a variety of likely mixotrophic taxa, which supports the idea that mixotrophy may be important for the survival of diverse protists through the long polar night.

Keywords: North Pole, arctic, plankton, protist diversity, sea ice, dinoflagellates, alveolates

\section{INTRODUCTION}

One of the most characteristic features of the Arctic Ocean is its permanent sea ice cover, which is a present source of concern because of its steady decline linked to global warming (Lemke et al., 2007). The logistical constraints to sample the northernmost sites on Earth due to harsh environmental conditions are still an obstacle to biodiversity and ecological studies in such high latitudes, especially during maximum sea ice cover periods (Comiso, 2003). Despite these limitations, it is known that sea ice offers an exclusive habitat for a diverse microbial community in polar environments (see review in Mock and Thomas, 2005). A special attention has been paid to dominant species, mostly unicellular algae and heterotrophic bacteria. A variety of protist species have also been reported in Arctic sea ice and seawater by traditional morphology-based methods (e.g., Horner, 1985; Lizotte, 2003; Olli et al., 2007). Diatoms, which significantly contribute to the primary production in the Arctic Ocean (see review by Arrigo, 2003), are by far the best studied protist group in these waters (Palmisano and Garrison, 1993; Ikävalko and Thomsen, 1997; Melnikov, 1997). However, a wide diversity of other eukaryotes is also present in Arctic sea ice and underlying waters. Marine microorganisms may be trapped during ice formation and remain inactive and frozen, but also active microorganisms live in brine-channel systems within the ice, being subjected to strong physical and chemical constraints (e.g., temperature, salinity, light, nutrients) which vary both spatially and temporally (Eicken, 2003). These parameters reach extreme values during winter, not only within the ice but also in the ice-covered Arctic Ocean that, with an average depth of approximately $1000 \mathrm{~m}$, is an environment characterized by very limited light and extremely low temperatures. The sea ice is typically $2 \mathrm{~m}$ thick and the snow cover up to $28 \mathrm{~cm}$ thick (Richter-Menge et al., 2006). However, the information about microbial communities associated with the multi-year ice cover is very limited (Thomas et al., 1995; Perovich et al., 1999; Werner et al., 2007), especially during winter and in central areas of the Arctic Ocean, where the water column depths are the highest (4179 $\mathrm{m}$ at the North Pole; maximum depth $5450 \mathrm{~m}$ at the European basin).

During the last decade, environmental studies of eukaryotic diversity based on polymerase chain reaction (PCR) amplification, cloning, and sequencing of the $18 \mathrm{~S}$ rRNA gene have revealed a wide diversity of protists in a variety of poorly explored habitats (López-García et al., 2001; Moon-Van Der Staay et al., 2001; Moreira and López-García, 2002; Richards and Bass, 2005). So far, 
only a few molecular studies of protist diversity have been carried out in very high-latitude oceanic regions. Gast et al. (2004) reported the first molecular survey of the microbial eukaryotes from sea ice environments in the Antarctic Ross Sea, showing a large genetic diversity and a certain degree of habitat specificity. In the high Arctic, molecular methods were used to study protist diversity in nearshore fast ice and waters (Lovejoy et al., 2006; Terrado et al., 2009; Eddie et al., 2010), fjords (Luo et al., 2009; Piquet et al., 2010), sediments (Stoeck et al., 2007; Tian et al., 2009) and, very recently, snow (Harding et al., 2011). However, the diversity and vertical distribution of microbial eukaryotic communities in Arctic offshore environments remains to be studied.

Samples collected during the Barneo-2008 expedition (MarchApril 2008) offered us the opportunity to explore the highest latitudes on Earth at the very end of the polar night. Here, we report the diversity and vertical distribution of microbial eukaryotes of sizes comprised between 0.2 and $200 \mu \mathrm{m}$ in the multi-year sea ice, the underlying waters and the snow covering the sea ice from a sampling site located at close proximity to the geographic North Pole.

\section{MATERIALS AND METHODS SAMPLE COLLECTION}

Samples were collected during the Barneo-2008 expedition ${ }^{1}$, a Russian initiative organized as part of the 2007-2008 International Polar Year. This expedition was based on the installation of a scientific camp on a large ice floe of several kilometers of diameter drifting in the North Pole region. Scientists occupied the camp for 1 month (from March 15th to April 15th) while the ice floe freely drifted from the original location, $\mathrm{N} 89^{\circ} 36^{\prime}, \mathrm{E} 118^{\circ} 49^{\prime}$, to one more to the South, $\mathrm{N} 88^{\circ} 28^{\prime}, \mathrm{E} 12^{\circ} 47^{\prime}$ (Figure 1A), Because of logistic

${ }^{1}$ http://barneo.ru/2008e.htm
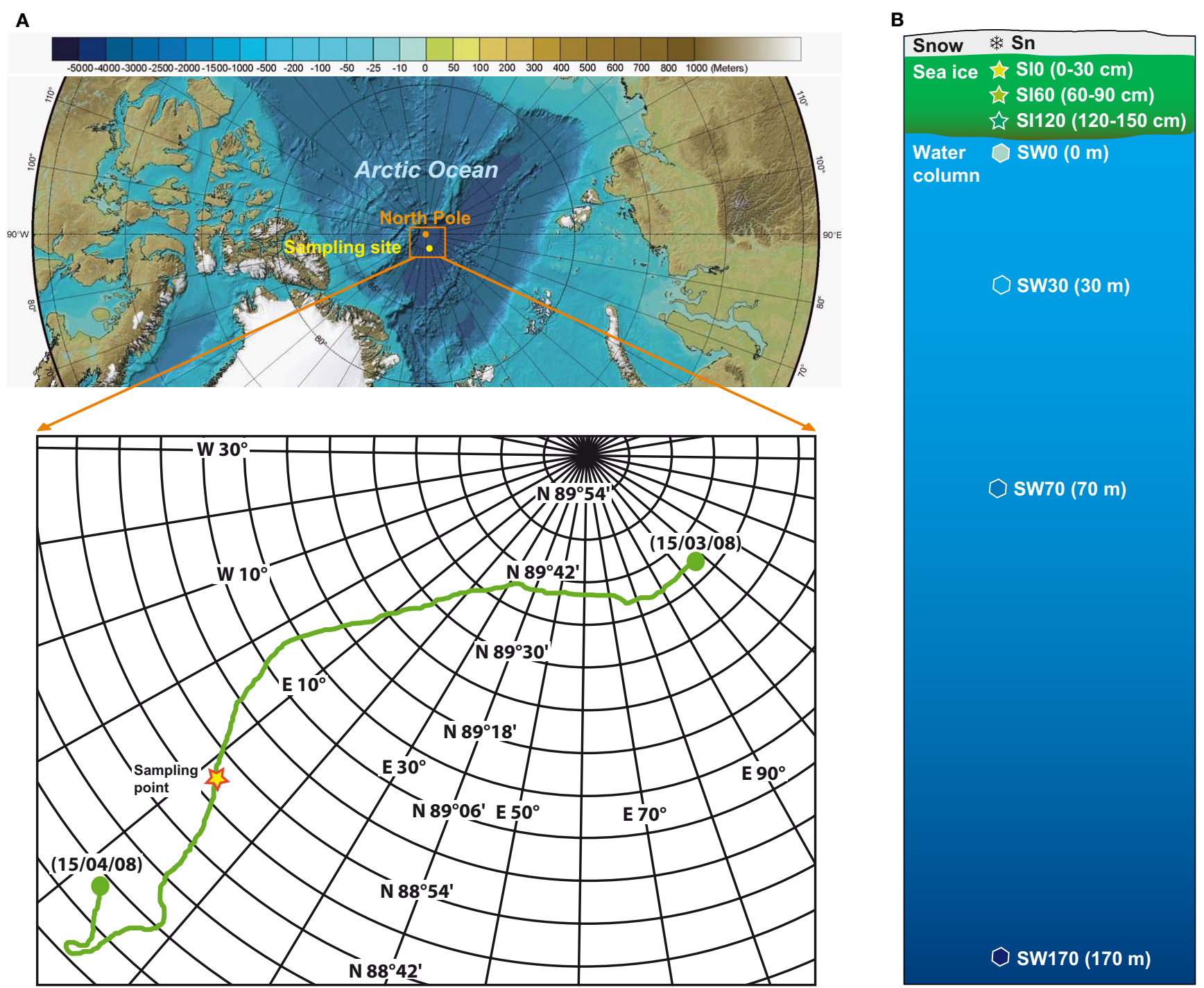

FIGURE 1 | Origin of samples. (A) Sampling site in the Arctic Ocean, the boxed area shows the path of the Barneo-2008 expedition; (B) profile of the sampling depths from the upper snow layer, through the ice cover, to the bottom of the euphotic zone. Base map is the International Bathymetric Chart of the Arctic Ocean (Jakobsson et al., 2008). 
reasons and to wait until the very end of the polar night, samples were taken at an intermediate location (N88 $35^{\prime}$, E015 $\left.{ }^{\circ} 59\right)$ between April 4th and 11th. These samples corresponded to different depths along a vertical profile (Figure 1B), from the snow cover (1 sample of $4 \mathrm{l}$ ), through the $1.5-\mathrm{m}$ thick multi-year sea ice (three samples of 4 l each, at depths $0-30,60-90$, and 120-150 cm) to the epipelagic zone of the underlying water column (four samples at 0, 30, 70 , and $170 \mathrm{~m}$ depth). Snow was collected with a sterile bucket, sea ice with a sterile ice driller $(11 \mathrm{~cm}$ of diameter), and seawater with a 5-1 Niskin bottle. Seawater was collected directly under the sea ice trough the hole opened during the sea ice sampling. Snow and ice were melted at $4^{\circ} \mathrm{C}$ under sterile conditions. After passing water samples through a $200-\mu \mathrm{m}$ mesh, samples of approximately 4 (snow and ice) and 11 (seawater) were filtered through a GTTP Millipore $0.22 \mu \mathrm{m}$-pore-diameter filter. Filters containing the cells were fixed in absolute ethanol and conserved at $-20^{\circ} \mathrm{C}$ following a protocol already tested for plankton samples (López-García et al., 2003, 2007). DNA was purified from filters cut in small pieces using the Ultraclean MoBio Soil DNA kit (MoBio, Solana Beach, CA, USA). Nucleic acids were resuspended in $10 \mathrm{mM}$ Tris- $\mathrm{HCl}, \mathrm{pH} 8$.

\section{PCR AMPLIFICATION, CLONING, AND SEOUENCING}

Near full-length 18S rDNA fragments were amplified by PCR using the eukaryotic-specific primers $82 \mathrm{~F}$ (GAA ACT GCG AAT GGC TC) and 1498R (CAC CTA CGG AAA CCT TGT TA; López-García et al., 2003). PCR was carried out under the following conditions: 35 cycles (denaturation at $94^{\circ} \mathrm{C}$ for $15 \mathrm{~s}$, annealing at $50^{\circ} \mathrm{C}$ for $30 \mathrm{~s}$, extension at $72^{\circ} \mathrm{C}$ for $2 \mathrm{~min}$ ) preceded by $3 \mathrm{~min}$ denaturation at $94^{\circ} \mathrm{C}$, and followed by $10 \mathrm{~min}$ extension at $72^{\circ} \mathrm{C} .18 \mathrm{~S} \mathrm{rDNA}$ clone libraries were constructed using the Topo TA cloning system (Invitrogen) following the instructions provided by the manufacturer. Positive inserts of expected size were selected from each library and sequenced with the reverse primer. We obtained a total of 1000 high-quality partial sequences $(>700 \mathrm{bp}$ ) which served for a preliminary phylogenetic analysis and identification of operational taxonomic units (OTUs). For each library, we completely sequenced at least one clone per OTU (defined here as clusters of sequences having $>98 \%$ identity) to obtain complete sequences representative of the whole taxonomic diversity found. 175 complete sequences were thus retained after exclusion of 14 chimeras detected with KeyDNATools ${ }^{2}$ (Guillou et al., 2008). Sequences were submitted to GenBank (accession numbers HQ438100-HQ438190 and JF826314-JF826397)

\section{OTU IDENTIFICATION AND BIODIVERSITY ESTIMATES}

High-quality partial 18S rDNA sequences were aligned using MAFFT (Katoh et al., 2002) and a distance matrix was generated in Phylip format. The resulting matrix was used as input for MOTHUR ${ }^{3}$ (Schloss et al., 2009) in order to group sequences in OTUs at different identity levels and to compare communities using heatmaps.

\section{PHYLOGENETIC ANALYSES}

The 175 representative clones that were completely sequenced, together with their most similar sequences (both known species and/or environmental clones) identified by BLAST (Altschul

${ }^{2}$ http://www.keydnatools.com/

${ }^{3}$ http://www.mothur.org/ et al., 1997) in GenBank ${ }^{4}$, were aligned using MAFFT (Katoh et al., 2002). The multiple sequence alignment was then manually edited using the program ED from the MUST package (Philippe, 1993). A neighbor-joining (NJ) tree was constructed for all the taxa in order to choose representative subsets of sequences for further phylogenetic analyses. The first three datasets corresponded to a variety of ciliate, Marine Alveolate Group I (MAG I) and II (Syndiniales) and dinoflagellate sequences, which were found to be the most abundant and diverse. The two other datasets corresponded to metazoan, fungal, amoebozoan, green plant, rhizarian, and heterokont sequences, spanning the rest of the eukaryotic diversity found. These datasets were analyzed by maximum likelihood (ML) using TREEFINDER (Jobb et al., 2004) applying a general time reversible (GTR) model of sequence evolution with a 4 -rate categories Gamma law and invariant sites to accommodate for among-site rate variation. ML bootstrap proportions were inferred using 1000 replicates. Bayesian inference was also conducted using MrBayes (Huelsenbeck and Ronquist, 2001), starting with a random tree, ran for one million generations in four chains and excluding the first 3500 generations as "burn in." The ML and Bayesian analyses produced congruent topologies.

\section{RESULTS}

\section{MICROBIAL EUKARYOTIC DIVERSITY NEAR THE NORTH POLE}

Our clone libraries were clearly dominated by Alveolata, especially by the core dinoflagellates (Dinokaryota) and their close relatives Marine Alveolate Groups I (MAG I) and II (Syndiniales; Figure 2). Sequences affiliating to core dinoflagellates were the most abundant in all libraries from the water column, especially in our deepest seawater sample (W170, $170 \mathrm{~m}$ depth), where they represented up to $80 \%$ of clones. They were also dominant in sea ice, except for the sample SI60 where MAG I and II sequences were equally abundant and represented almost $40 \%$ of clones in this sample. In fact, MAG I and II were after dinoflagellates the most represented lineages in almost all the seawater and sea ice samples, though with varying proportions (Figure 2). Ciliate, heterokonts (stramenopiles), green algal, rhizarian, and fungal clones were detected in weak proportions in seawater and sea ice samples (from 1 to $7 \%$ ). We noticed the presence of sequences affiliated to animals in seawater and snow, reaching remarkable proportions in the surface seawater sample SW0 (29\% of clones of this library). A few sequences were identified as Amoebozoa in the deep seawater sample SW170 and as Telonemia in the deepest sea ice sample SI120. The composition of high-rank taxa in the snow sample was radically different from other samples with a large majority of fungal (72\%) and green plant $(20 \%)$ clones, strongly suggesting contamination (see below). The clone library from the deepest sea ice sample was the richest in terms of high-rank phylogenetic taxa diversity, whereas that from the snow sample was the poorest.

Using the criterion of $>98 \%$ sequence identity for the definition of OTUs, we observed a specific richness of, collectively, 98 OTUs in the water column, 62 OTUs in the sea ice, and only 4 OTUs in the snow. More precisely, the observed specific richness was similar between the pelagic samples and the bottom sea ice sample and slightly lower in the upper and middle sea ice layers (Table 1). In addition to these diversity estimations, we carried out a statistical

${ }^{4}$ http://www.ncbi.nlm.nih.gov/ 


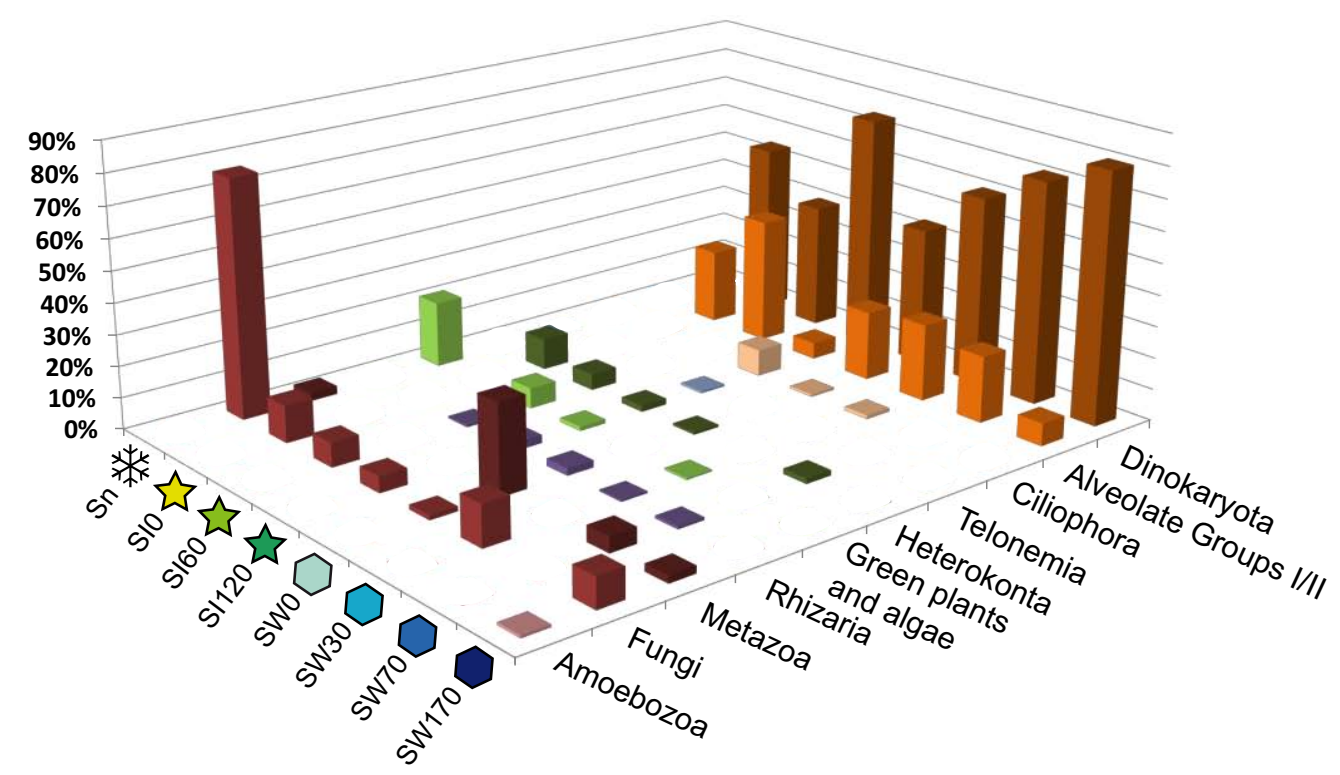

FIGURE 2 | Relative 18S rDNA abundance of major eukaryotic groups in gene libraries from samples near the North Pole. For sample names, see Figure 1.

Table 1 | Number of OTUs and clones in the North Pole clone libraries.

\begin{tabular}{llll}
\hline & OTUs $\mathbf{9 8 \%}$ & OTUs $\mathbf{9 5 \%}$ & Number of clones \\
\hline Snow & 4 & 4 & 38 \\
SI0 & 19 & 14 & 130 \\
SI60 & 25 & 21 & 155 \\
SI120 & 33 & 24 & 146 \\
Sea ice* & 62 & 45 & 431 \\
SW0 & 34 & 24 & 133 \\
SW30 & 44 & 31 & 154 \\
SW70 & 30 & 17 & 118 \\
SW170 & 29 & 19 & 125 \\
Seawater* & 98 & 60 & 530 \\
\hline
\end{tabular}

*Total values for all sea ice and water samples combined.

comparison of the overall eukaryotic diversity among samples using two different levels of sequence identity: $98 \%$ identity as a proxy for species boundaries and at 95\% identity as a proxy for genera. At $98 \%$ sequence identity, the seawater samples SW30 and W170 as well as the sea ice samples SI0 and SI60 were the closest among them, differing significantly from the rest (Figure 3). At 95\% sequence identity the differences between seawater samples and the deepest sea ice sample (SI120) were negligible (Figure 3), suggesting that differences in protist community composition between these samples concentrate at the species, but not genus, level. Likewise, the upper and middle sea ice samples (SI0 and SI60) appeared to be similar. Therefore, our analysis supports the partition of our samples into three groups in terms of their diversity of protist species and genera: (i) snow, (ii) the upper and middle sea ice layer, and (iii) the deepest sea ice layer and all the seawater samples (with the deepest sea ice layer being intermediate between the seawater and the upper ice layers, as expected).

\section{DIVERSITY OF ALVEOLATA}

As mentioned above, the alveolates were by far the most abundant and diverse group in both plankton and sea ice $18 \mathrm{~S}$ rDNA libraries. A few phylotypes related to marine ciliates were found at the interface of sea ice and marine waters (Figure 4) but, as has been observed in many other marine plankton samples, alveolate phylotypes belonging to dinoflagellates and the parasitic MAG I and Syndiniales (MAG II) were dominant in libraries, representing more than $78 \%$ of the 1000 partially sequenced clones. Seven seawater OTUs grouped with Syndiniales representatives, some of which had already been detected in other marine locations (LópezGarcía et al., 2007; Not et al., 2007; Guillou et al., 2008), and two clones (SI120-63 and SW30-39) branched within a well-supported cluster grouping Amoebophrya species (Figure 5). The Syndiniales are a dinoflagellate order composed of small marine parasites that appear to be highly diverse and abundant in environmental studies (López-García et al., 2001; Moon-Van Der Staay et al., 2001; Moreira and López-García, 2003). They can infect a variety of hosts, from marine animals to protists, though many of them are specific parasites of other dinoflagellates (e.g., Amoebophrya spp., Chambouvet et al., 2008). The presence of a large diversity of core dinoflagellates in our samples (see below) could explain, at least partially, the abundance and diversity of Syndiniales observed in the same samples. The MAG I, which have also been retrieved abundantly in various marine environments (see López-García et al., 2001; Moon-Van Der Staay et al., 2001; Massana et al., 2004; Romari and Vaulot, 2004; Dolven et al., 2007; Harada et al., 2007; Not et al., 2007), encompassed a larger genetic diversity than Syndiniales in our samples, being identified in all samples from $170 \mathrm{~m}$ depth to top of sea ice (Figure 5). We detected two large MAG I clades, one encompassing Duboscquella and Ichthyodinium sequences, and the other without any described species so far, but only environmental sequences coming from both coastal and oceanic ecosystems (Lin et al., 2006; Not et al., 2007; Behnke et al., 2010). 

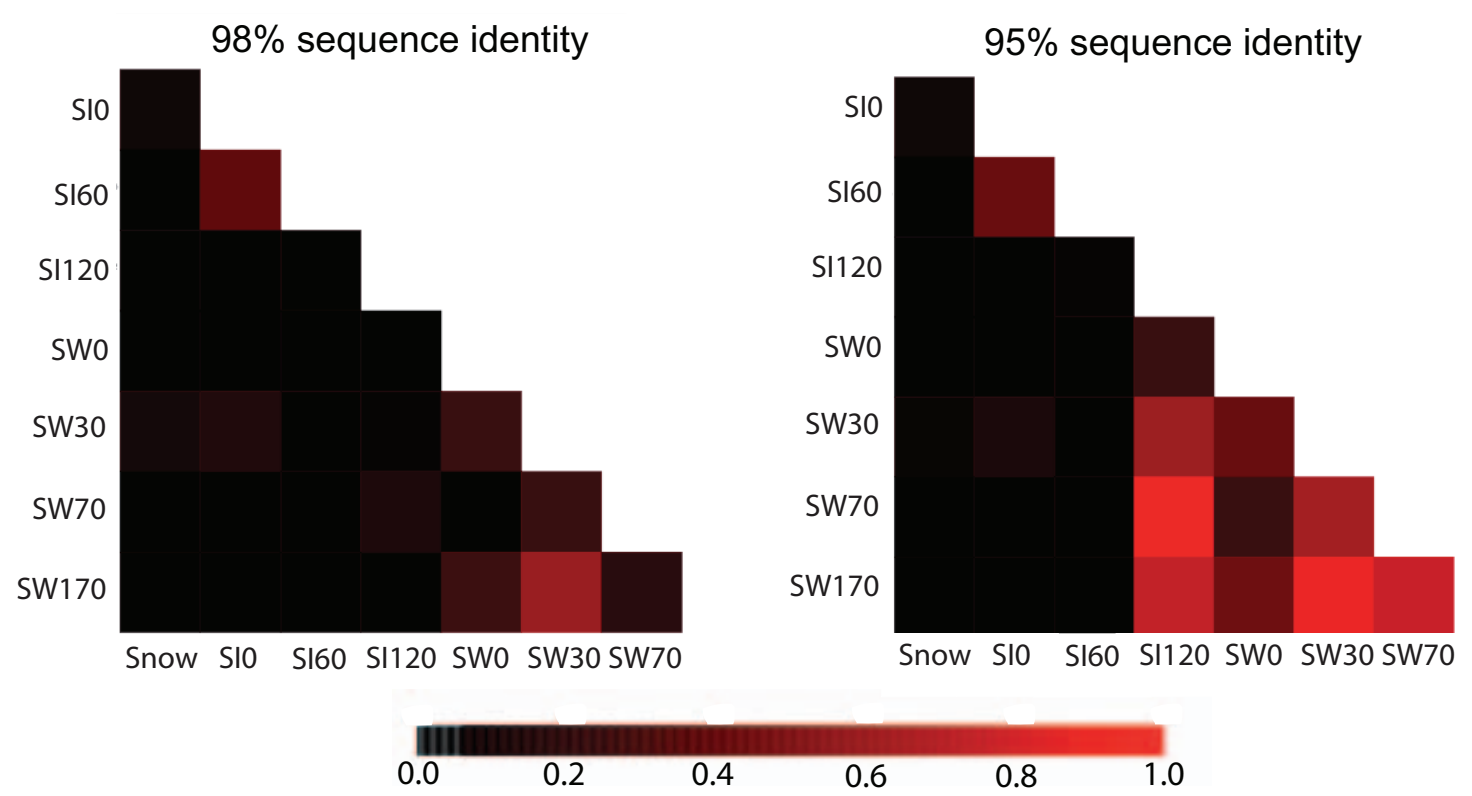

FIGURE 3 | Heatmaps comparing the diversity of eukaryotes among samples using the shared OTUs defined at clustering identity of $\mathbf{9 8 \%}$ (left) or $95 \%$ (right). Scale bar: Theta ${ }_{Y C}$ coefficient as measure of similarity between the structures of two communities, ranging from 0 (black) to 1 (red).

The core dinoflagellate phylotypes showed a very remarkable diversity (Figure 6), in agreement with several studies based on traditional methods showing the dominance of small flagellates, especially dinoflagellates, in the central Arctic Ocean during summer (Booth and Horner, 1997; Gradinger, 1999; Olli et al., 2007). Therefore, it seems that dinoflagellates are also diverse and abundant at the end of the polar night, in both the sea ice and seawater. Several of our dinoflagellate phylotypes grouped with cultured species usually observed in cold water environments, such as Protoperidinium sp. (phylotypes detected in the seawater samples), Scrippsiella hangoei, Polarella glacialis and Gymnodinium spp. (phylotypes detected in both the seawater and sea ice samples), and Woloszynskia halophila (phylotypes detected in the SI120 sea ice sample). Other phylotypes, such as SW30-129, SW70-41, SW30-6, SI120-47, SW70-35, or SW0-135 had other environmental sequences as very close relatives, some of which came from cold waters, e.g., SIF 1E11 and W159F8, coming from a Norwegian fjord and the Ross Sea, respectively (Gast et al., 2006; Behnke et al., 2010). Interestingly, an OTU (represented by SI0-102) detected in seawater and sea ice formed a divergent environmental clade with no close relatives in GenBank. A similar case was shown by several seawater sequences (represented by SW170-19) 99\% identical to the Sargasso Sea environmental sequence SCM27C4, which formed a fast evolving cluster characterized by a very long basal branch. Intriguingly, five phylotypes (SW30-106, SI60-101, SI6019, SI60-129, and SW0-75) formed a group well nested within dinokaryotic dinoflagellates without any closely related cultured species or environmental sequence. In fact, our results indicated that a large part of the core dinoflagellate phylotypes found in all the water and sea ice samples was related to undescribed species. Nevertheless, the two most abundant phylotypes, SW70-6 and
SW70-12, were closely related to the well known heterotrophic species Gyrodinium spirale and G. rubrum, respectively. Both phylotypes were frequent at all depths in the water column, specially the G. rubrum-like SW70-12, with a total of 88 occurrences (Figure 6), namely $\sim 9 \%$ of all our sequences, which was a remarkable value for a single species.

\section{OTHER EUKARYOTIC TAXA}

In contrast with the large diversity of alveolates, we only retrieved a limited variety of other eukaryotic groups in our North Pole samples, including several phylotypes belonging to the Metazoa, the Fungi, and the Amoebozoa. Within the Fungi, Basidiomycota, found in the snow, all the sea ice horizons and the water column, were the most diverse, whereas Ascomycota were only detected in both sea ice and seawater (Figure 7). Most of the ascomycete phylotypes were very closely related to Penicillium chrysogenum, a common airborne fungus (Wu et al., 2003). The marine fungi are well known to be heterotrophs that play an essential role as decomposers of organic matter (Kohlmeyer and Kohlmeyer, 1979; Newell, 1996), and their diversity in our samples suggested a similar potential role in high-latitude environments. We identified three animal phylotypes, one copepod and one annelid in the water samples. We also detected a human sequence in the snow sample, which corresponded obviously to a contaminant likely introduced during sampling and that we kept in our analyses to illustrate the fact that microbial diversity in the snow was very low, and possibly entirely composed of inactive organisms or dispersal forms, namely exogenous contaminant sequences. This was clearly the case for the snow phylotype $\mathrm{Sn}-26$, closely related to the temperate-climate terrestrial plant Pilea cadierei, and also for the sea ice phylotype SI60-38, very similar to Pinus sequences (Figure 8). These two phylotypes most 


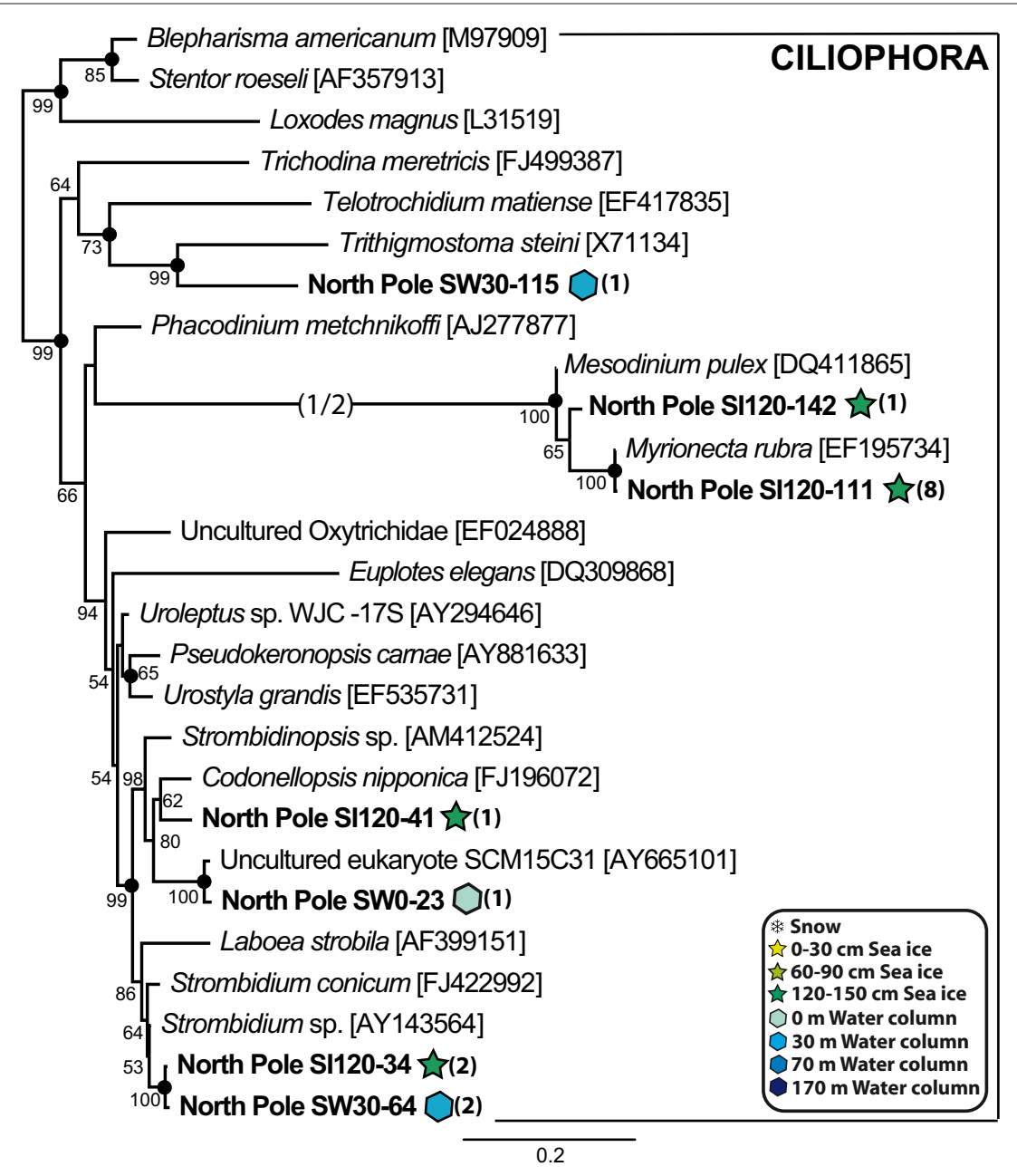

FIGURE 4 | Maximum likelihood phylogenetic tree of ciliate phylotypes. Names in italics correspond to cultivated species or strains, while the rest correspond to $18 \mathrm{~S}$ rDNA environmental clones. Names in bold correspond to clones retrieved in this study, numbers in parentheses indicating the number of clones for each phylotype in the different libraries. Accession numbers are given in brackets. Long branches shortened to one half of their length are indicated by (1/2). Maximum likelihood bootstrap values above $50 \%$ are indicated at nodes, and Bayesian posterior probabilities higher than 0.90 are indicated by filled circles. likely corresponded to pollen contaminants, pollen grains being well known to be able to traverse long distances with the help of wind currents (e.g., Campbell et al., 1999).

The diversity of heterokonts (or stramenopiles) was relatively large, with seven North Pole phylotypes (Figure 8). Only three of them corresponded to presumable photosynthetic species: SW7032 and SW0-77, which branched among diatoms very close to Actinocyclus curvatulus and Thalassiosira antarctica, two typical sea ice diatom species (Hasle and Heimdal, 1998), and SI120-23, which was very similar to an environmental clone from an anoxic Norwegian fjord, NIF-1D10, branching with the dictyochophyte Dictyocha speculum. The other four heterokont phylotypes were related to likely heterotrophic species: SI60-86 clustered within the environmental clade MAST-12 characterized by Kolodziej and Stoeck (2007), SI120-114 with Pirsonia punctigera, a parasitoid nanoflagellate that infects planktonic diatoms (Kühn et al., 2004), and SI0-36 and SI60-27 with the colorless chrysophytes Spumella sp. and Ochromonas sp. The rest of phylotypes showed a similar trend, a predominance of heterotrophic organisms; the only apparent exception being the phylotype SI120-29 affiliated to the prasinophyte green algae, commonly detected in Arctic samples (Lovejoy et al., 2006, 2007). Other eukaryotes in our samples (Figure 8) included one amoebozoan (SW170-108) in the deepest marine sample (170 m depth), the sea ice phylotype SI120-102, very similar to the flagellate Telonema subtile, and three phylotypes belonging to the Rhizaria, including two radiolaria (SW30-113 and SW70-42) found at different depths of the water column, and a cercozoan from sea ice (SI60-153) related to the species Cryothecomonas aestivalis, which is a diatom predator isolated from the North Sea (Drebes et al., 1996).

\section{DISCUSSION}

The taxonomic affiliation of the eukaryotic sequences associated to the snowpack sample was markedly different from that of the underlying sea ice and seawater. Snow was characterized by a clear dominance of fungal, fundamentally basidiomycete, and land plant 


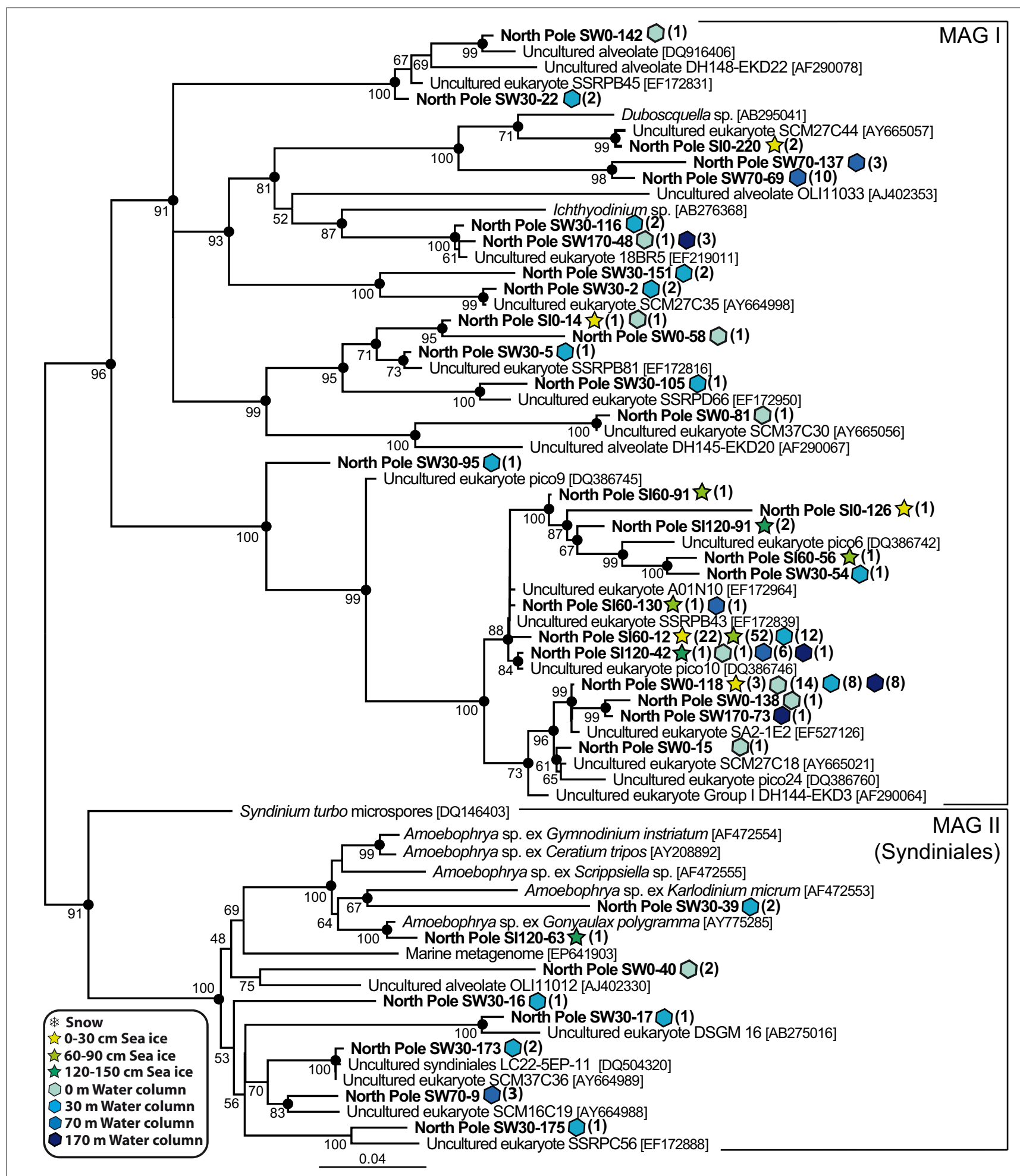

FIGURE 5 | Maximum likelihood phylogenetic tree of Marine Alveolate Group I and II (Syndiniales) phylotypes. The tree was rooted with perkinsozoan sequences (not shown).

sequences (Figure 2). This could be easily explained by the high production of easily wind-dispersive spores and pollen grains by these organisms. Undoubtedly, these eukaryotic sequences did not correspond to active organisms and, hence, our study attests to their cosmopolitan dispersal even to very remote regions. This was in agreement with a recent study of the diversity of microbes in 


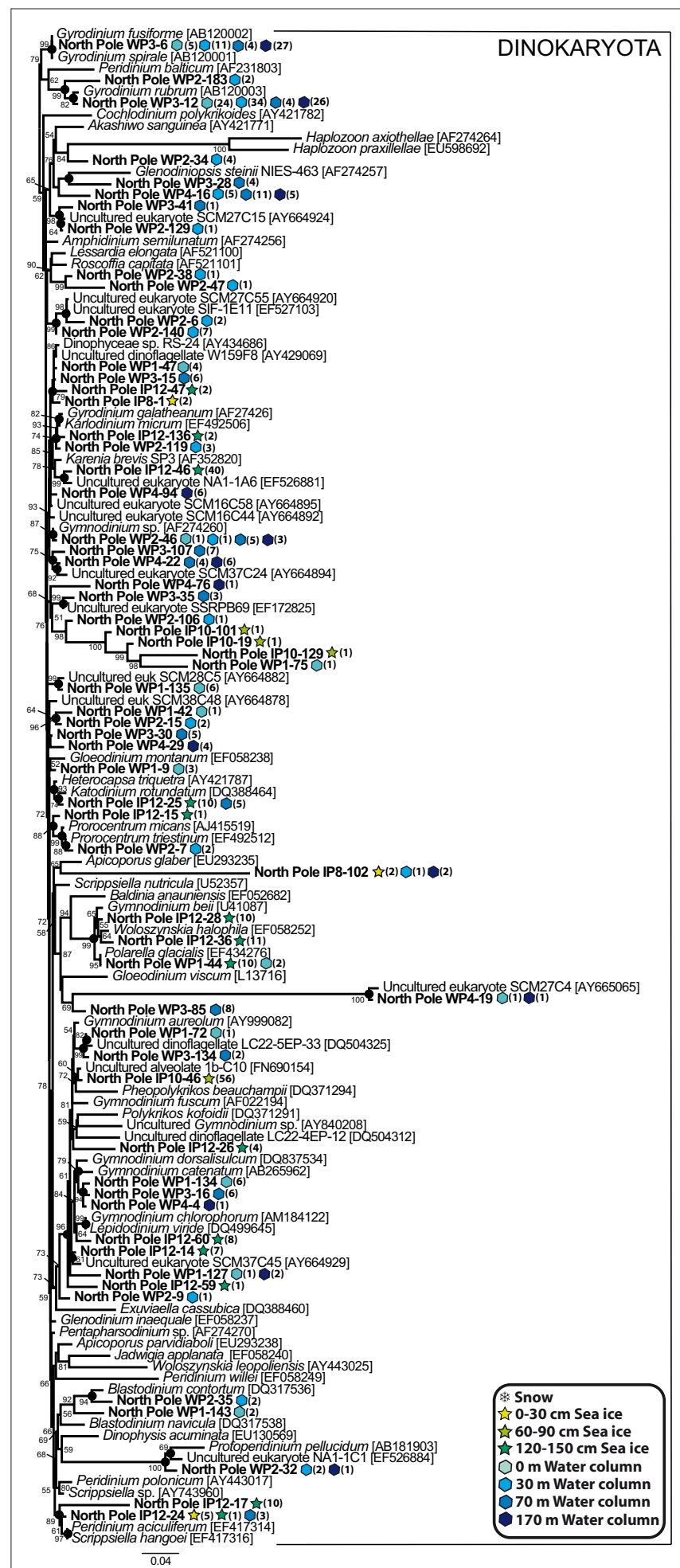

FIGURE 6 | Maximum likelihood phylogenetic tree of core dinoflagellate phylotypes. The tree was rooted with perkinsozoan sequences (not shown).

High Arctic snow samples showing the significant role played by wind in the aerial transport of microorganisms in this environment (Harding et al., 2011). In contrast with snow, the diversity of micro- bial eukaryotes in sea ice and seawater was much more similar in terms of relative abundances of phyla, with typical marine protist lineages being present in sea ice, most notably core dinoflagellates, MAG I and Syndiniales. This comforted the traditional idea that organisms in the sea ice mostly derive from the trapping of marine protists during ice formation (Garrison et al., 1983; Lizotte, 2003). Whether these organisms are active in briny ice creeks, inactive waiting for ice to melt or both in varying proportions, remains to be determined, though previous studies have shown that sea ice can host complex active ecological webs (Brierley and Thomas, 2002; Lizotte, 2003).

The abundance of Syndiniales and, especially, MAG I phylotypes in North Pole sea ice and water samples is in line with numerous observations of these groups in different water masses and oceanic regions (Moreira and López-García, 2002; Harada et al., 2007; Guillou et al., 2008), indicating that parasitism is an important component also in these polar marine ecosystems. More precisely, the simultaneous abundance of very diverse core dinoflagellates species in the same samples supports the hypothesis that, at least partly, a number of these parasites may infect some of these dinoflagellate species. Nevertheless, we cannot discard that a proportion of the parasites detected in sea ice might correspond to dormant forms inactive during winter in the absence of their hosts, so that sea ice might serve as a seed bank of parasites waiting for favorable environmental conditions. More surprisingly, we detected only two diatom phylotypes in our samples (representing only 3 sequences among the 1000 analyzed in this work), which was not concordant with previous taxonomical and molecular studies made on Arctic environments showing a high abundance of diverse diatom species (Lizotte, 2003; Gast et al., 2004; Lovejoy et al., 2006; Eddie et al., 2010). Although it is known that methodological biases in clone libraries can lead to artificial low frequencies of prasinophytes and diatoms (Potvin and Lovejoy, 2009), this observation could be the result of the severe light limitation during polar winter that would decrease primary production and/or to possible grazing pressure by heterotrophs limiting algal accumulation. In fact, we obtained evidence supporting these two possibilities. On the one hand, we detected several phylotypes in closely related to typical diatom predators such as Pirsonia, Cryothecomonas and, notably, the dinoflagellate Gyrodinium spirale, a voracious diatom predator (Sherr and Sherr, 2007) which was one of the most abundant organisms found in our samples (see above). On the other hand, other phototrophic protists typical of Arctic regions, such as the prasinophyte green algae (Lovejoy et al., 2007), were almost completely absent from our libraries, in agreement with the very low chlorophyll concentration measured in the water column $\left(<0.03 \mu \mathrm{g} \mathrm{l}^{-1}\right.$, V.I. Gagarin, personal communication). Likewise, among the dinoflagellate phylotypes for which we could infer their lifestyle based on their close proximity to known species, only one, SW0-44, related to the common sea ice species Polarella glacialis (Montresor et al., 1999), was a typical phototroph. It appeared that our samples were dominated by non-photosynthetic species much more extensively than commonly found in marine 18S rRNA gene libraries (Vaulot et al., 2002). The simplest explanation for this result can be that our samples were collected at the very end of the 6-month polar night, an extremely challenging period for phototrophic species that most likely decrease their density dramatically because of cell death and grazing pressure. 


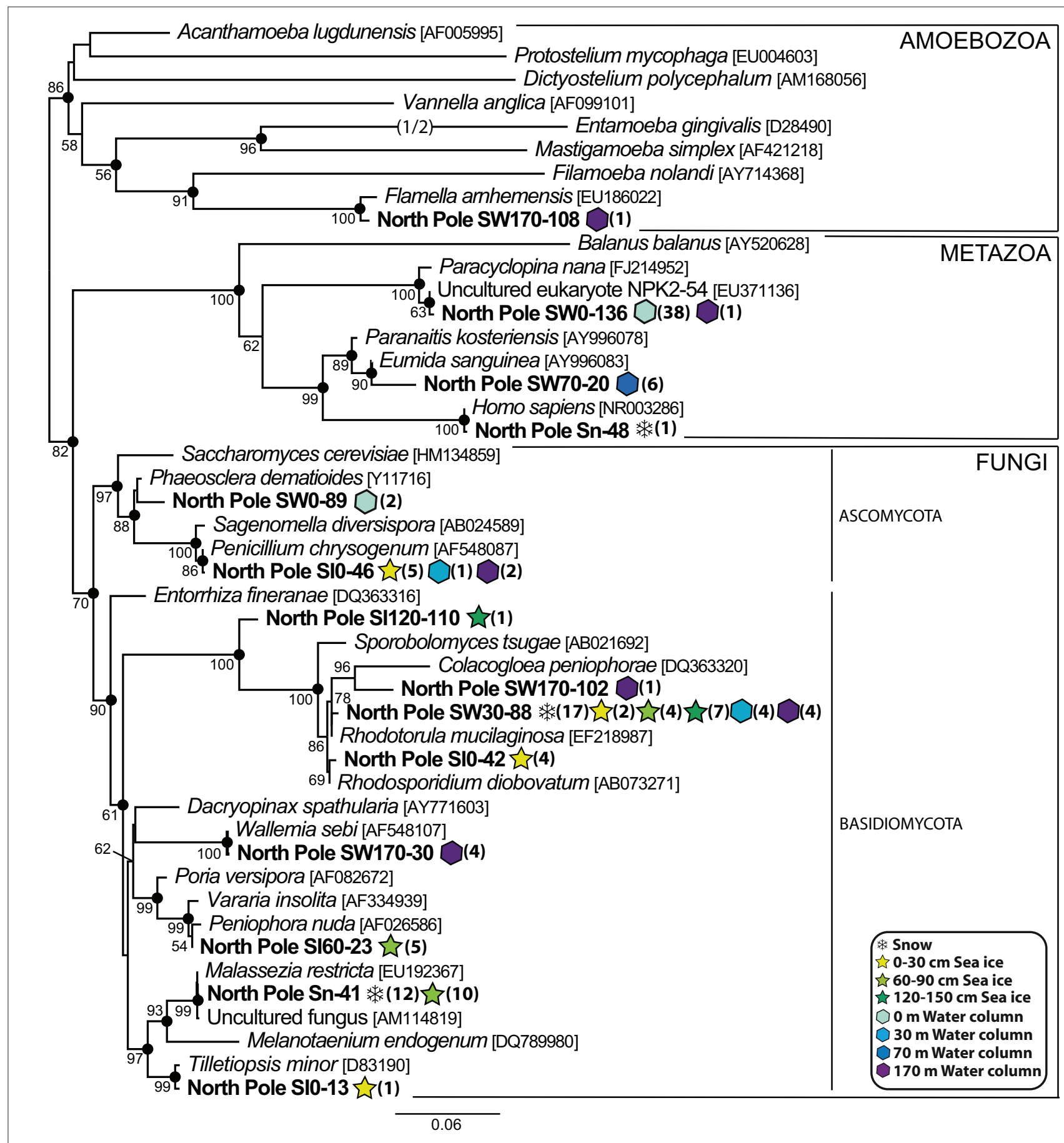

FIGURE 7 | Maximum likelihood phylogenetic tree of diverse animal, fungal and amoebozoan phylotypes.

The notable scarcity of phototrophic species in our libraries was compensated by a relatively large frequency of potential mixotrophic organisms. In fact, mixotrophy, a nutritional mode that combines autotrophy and heterotrophy, has been proposed to be a much more widespread strategy in marine and freshwater ecosystems than previously thought (Sanders, 1991; Jones, 2000), with a prominent role particularly in polar environments (Moorthi et al., 2009). Likely mixotrophic candidates in our samples were several of the dinoflagellate phylotypes, especially those closely related to species of the genera Gyrodinium, Gymnodinium, Blastodinium, Katodinium, Prorocentrum, and Woloszynskia (Sherr and Sherr, 2007; Yoo et al., 2009; Kang et al., 2011), some of them at relatively high frequencies (Figure 6), as well as the ciliate phylotypes closely 


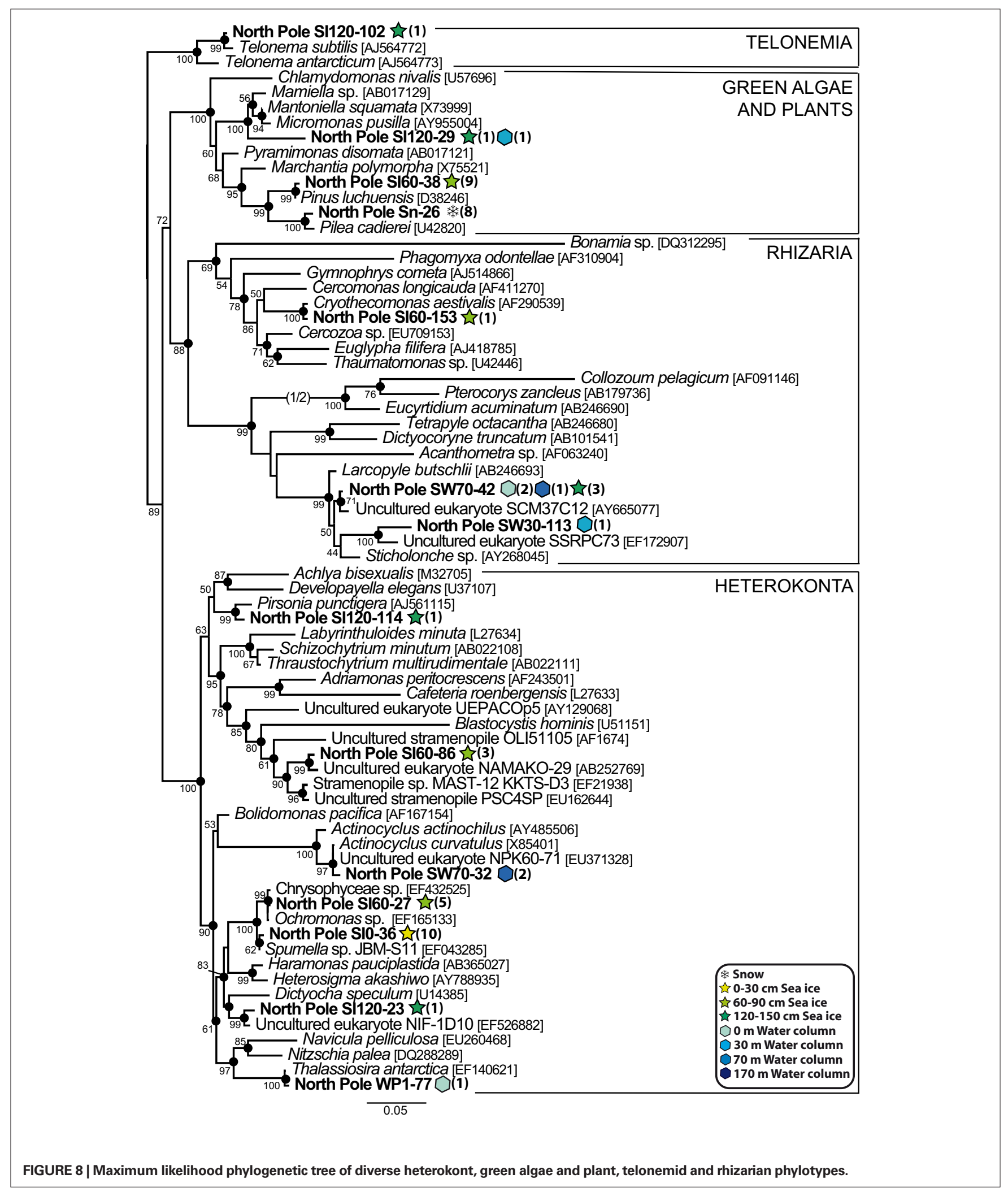

related to Myrionecta rubra and Strombidium conicum, which possess plasts obtained from partial digestion of algal prey (Gustafson et al., 2000; Johnson and Stoecker, 2005; Myung et al., 2006). These observations suggest that mixotrophy was probably more prevalent than strict phototrophy in our samples. As explained above, this was probably due to the particular 
nature of those samples, collected after several months of darkness (because of the polar night strongly accentuated by the shading effect of the snowpack and sea ice cover). Under that strong environmental constraint, not only typical heterotrophs but also mixotrophs are advantaged over the phototrophic species. The atypical character of our samples, collected at the end of the polar night, made possible to detect with relatively high frequencies organisms that are otherwise rare in samples collected mostly in other seasons, when typical phototrophs largely dominate. Future temporal studies with samples taken

\section{REFERENCES}

Altschul, S. F., Madden, T. L., Schaffer, A. A., Zhang, J., Zhang, Z., Miller, W., and Lipman, D. J. (1997). Gapped BLAST and PSI-BLAST: a new generation of protein database search programs. Nucleic Acids Res. 25, 3389-3402.

Arrigo, K. R. (2003). "Primary production in sea ice," in Sea Ice - An Introduction to its Physics, Chemistry, Biology and Geology, eds D. N. Thomas and G. S. Dieckmann (Oxford: Blackwell Publishing), 143-183.

Behnke, A., Barger, K. J., Bunge, J., and Stoeck, T. (2010). Spatio-temporal variations in protistan communities along an $\mathrm{O} / \mathrm{HS}$ gradient in the anoxic Framvaren Fjord (Norway). FEMS Microbiol. Ecol. 72, 89-102.

Booth, B. C., and Horner, R. A. (1997). Microalgae on the Arctic Ocean section, 1994: species abundance and biomass. Deep Sea Res. Part II Top. Stud. Oceanogr. 44, 1607-1622.

Brierley, A. S., and Thomas, D. N. (2002). Ecology of southern ocean pack ice. Adv. Mar. Biol. 43, 171-276.

Campbell, I. D., Mcdonald, K., Flannigan, M. D., and Kringayark, J. (1999). Longdistance transport of pollen into the Arctic. Nature 399, 29-30.

Chambouvet, A., Morin, P., Marie, D., and Guillou, L. (2008). Control of toxic marine dinoflagellate blooms by serial parasitic killers. Science 322, 1254-1257.

Comiso, J. C. (2003). "Large scale characteristics and variability of the global sea ice cover," in Sea ice - An Introduction to its Physics, Chemistry, Biology and Geology, eds D. N. Thomas and G. S. Dieckmann (Oxford: Blackwell Publishing), 112-142.

Dolven, J. K., Lindqvist, C., Albert, V. A., Bjorklund, K. R., Yuasa, T., Takahashi, O., and Mayama, S. (2007). Molecular diversity of alveolates associated with neritic north atlantic radiolarians. Protist 158, 65-76.

Drebes, G., Kühn, S., Gmelch, A., and Schnepf, E. (1996). Cryothecomonas aestivalis sp. nov., a colourless nanoflagellate feeding on the marine centric diatom Guinardia delicatula; (Cleve) Hasle. Helgol. Mar. Res. 50, 497-515.
Eddie, B., Juhl, A., Krembs, C., Baysinger, C., and Neuer, S. (2010). Effect of environmental variables on eukaryotic microbial community structure of land-fast Arctic sea ice. Environ. Microbiol. 12, 797-809.

Eicken, H. (2003). "From the microscopic, to the macroscopic, to the regional scale," in Sea Ice - An Introduction to its Physics, Chemistry, Biology and Geology, eds D. N. Thomas and G. S. Dieckmann (Oxford: Blackwell Publishing), 22-81.

Garrison, D. L., Ackley, S. F., and Buck, K. R. (1983). A physical mechanism for establishing algal populations in frazil ice. Nature 306, 363-365.

Gast, R. J., Dennett, M. R., and Caron, D. A. (2004). Characterization of protistan assemblages in the Ross Sea, Antarctica, by denaturing gradient gel electrophoresis. Appl. Environ. Microbiol. 70, 2028-2037.

Gast, R. J., Moran, D. M., Beaudoin, D. J., Blythe, J. N., Dennett, M. R., and Caron, D. A. (2006). Abundance of a novel dinoflagellate phylotype in the Ross sea, Antarctica. J. Phycol. 42, 233-242.

Gradinger, R. (1999). Vertical fine structure of the biomass and composition of algal communities in Arctic pack ice. Mar. Biol. 133, 745-754.

Guillou, L., Viprey, M., Chambouvet, A., Welsh, R. M., Kirkham, A. R., Massana, R., Scanlan, D. J., and Worden, A. Z. (2008). Widespread occurrence and genetic diversity of marine parasitoids belonging to Syndiniales (Alveolata). Environ. Microbiol. 10, 3349-3365.

Gustafson, D. E., Stoecker, D. K., Johnson, M. D., Van Heukelem, W. F., and Sneider, K. (2000). Cryptophyte algae are robbed of their organelles by the marine ciliate Mesodinium rubrum. Nature 405, 1049-1052.

Harada, A., Ohtsuka, S., and Horiguchi, T. (2007). Species of the parasitic genus Duboscquella are members of the enigmatic marine Alveolate group I. Protist $158,337-347$

Harding, T., Jungblut, A. D., Lovejoy, C., and Vincent, W. F. (2011). Microbes

regularly all along the polar night will be useful to better understand how this shift in the composition of the microbial community occurs.

\section{ACKNOWLEDGMENTS}

This work was supported by the French Agence Nationale de la Recherche (ANR) project "Aquaparadox" (ANR BDIV 07 00402). We acknowledge Dr. V. I. Gagarin (Institute of Oceanology, Moscow, Russia) who collected samples during the Palex Expedition on Barneo ice floe.

in high Arctic snow and implications for the cold biosphere. Appl. Environ. Microbiol. doi:10.1128/AEM.0261110. [Epub ahead of print].

Hasle, G. R., and Heimdal, B. R. (1998). The net phytoplankton in Kongsfjorden, Svalbard, July 1988 with general remarks on species composition of arctic phytoplankton. Polar Res. 17, 31-52.

Horner, R. (1985). Sea Ice Biota. Boca Raton, FL: CRC Press.

Huelsenbeck, J.P., and Ronquist, F. (2001). MRBAYES: Bayesian inference of phylogenetic trees. Bioinformatics 17, 754-755.

Ikävalko, J.U., and Thomsen, H.A. (1997). Baltic sea ice biota (March 1994): a study of the protistan community. Eur. J. Protistol. 33, 229-243.

Jakobsson, M., Macnab, R., Mayer, L., Anderson, R., Edwards, M., Hatzky, J., Schenke, H.W., and Johnson, P. (2008) An improved bathymetric portrayal of the Arctic Ocean: implications for ocean modeling and geological, geophysical and oceanographic analyses. Geophys. Res. Lett. 35, L07602.

Jobb, G., Von Haeseler, A., and Strimmer, K. (2004). TREEFINDER: a powerful graphical analysis environment for molecular phylogenetics. BMC Evol. Biol. 4, 18. doi 10.1186/1471-2148-4-18

Johnson, M. D., and Stoecker, D. K. (2005). Role of feeding in growth and photophysiology of Myrionecta rubra. Aquat. Microb. Ecol. 39, 303-312.

Jones, R. I. (2000). Mixotrophy in planktonic protists: an overview. Freshw. Biol. 45, 219-226.

Kang, N. S., Jeong, H. J., Yoo, Y. D., Yoon, E. Y.,Lee, K.H.,Lee, K., and Kim, G. (2011). Mixotrophyin thenewly described phototrophic dinoflagellate Woloszynskia cincta from Western Korean waters: feeding mechanism, prey species and effect of prey concentration. J. Eukaryot. Microbiol. 58, 152-170.

Katoh, K., Misawa, K., Kuma, K., and Miyata, T. (2002). MAFFT: a novel method for rapid multiple sequence alignment based on fast Fourier transform. Nucleic Acids Res. 30, 3059-3066.
Kohlmeyer, J., and Kohlmeyer, E. (1979). Marine Mycology: The Higher Fungi. New York, NY: Academic Press.

Kolodziej, K., and Stoeck, T. (2007). Cellular Identification of a novel uncultured marine stramenopile (MAST-12 Clade) small-subunit rRNA gene sequence from a Norwegian estuary by use of fluorescence In situ hybridization-scanning electron microscopy. Appl. Environ. Microbiol. 73, 2718-2726.

Kühn, S., Medlin, L., and Eller, G. (2004). Phylogenetic position of the parasitoid nanoflagellate Pirsonia inferred from nuclear-encoded small subunit ribosomal DNA and a description of Pseudopirsonia n. gen. and Pseudopirsonia mucosa (Drebes) comb. nov. Protist 155, 143-156.

Lemke, P., Ren, J., Alley, R. B., Allison, I., Carrasco, J., Flato, G., Fujii, Y., Kaser, G., Mote, P., Thomas, R. H., and Zhang, T. (2007). "Observations: changes in snow, ice and frozen ground," in Climate Change 2007: The Physical Science Basis. Contribution of Working Group I to the Fourth Assessment Report of the Intergovernmental Panel on Climate Change, eds S. Solomon, D. Qin, M. Manning, Z. Chen, M. Marquis, K. B. Averyt, M. Tignor, and H. L. Miller (Cambridge: Cambridge University Press), 337-383.

Lin, S., Zhang, H., Hou, Y., Miranda, L., and Bhattacharya, D. (2006). Development of a dinoflagellateoriented PCR primer set leads to detection of picoplanktonic dinoflagellates from Long Island Sound. Appl. Environ. Microbiol. 72, 5626-5630.

Lizotte, M. P. (2003). "The microbiology of sea ice," in Sea Ice - An Introduction to its Physics, Chemistry, Biology and Geology, eds D. N. Thomas and G. S. Dieckmann (Oxford: Blackwell Publishing), 184-210.

López-García, P., Philippe, H., Gail, F., and Moreira, D. (2003). Autochthonous eukaryotic diversity in hydrothermal sediment and experimental microcolonizers at the Mid-Atlantic Ridge. Proc. Natl. Acad. Sci. U.S.A. 100, 697-702. 
López-García, P., Rodriguez-Valera, F., Pedros-Alio, C., and Moreira, D. (2001). Unexpected diversity of small eukaryotes in deep-sea Antarctic plankton. Nature 409, 603-607.

López-García, P., Vereshchaka, A., and Moreira, D. (2007). Eukaryotic diversity associated with carbonates and fluid-seawater interface in Lost City hydrothermal field. Environ. Microbiol. 9, 546-554.

Lovejoy, C., Massana, R., and PedrósAlió, C. (2006). Diversity and distribution of marine microbial eukaryotes in the Arctic Ocean and adjacent seas. Appl. Environ. Microbiol. 72, 3085-3095.

Lovejoy, C., Vincent, W. F., Bonilla, S., Roy, S., Martineau, M. J., Terrado, R., Potvin, M., Massana, R., and PedrósAlió, C. (2007). Distribution, phylogeny, and growth of cold-adapted picoprasinophytes in Arctic seas. J. Phycol. 43, 78-89.

Luo, W., Li, H., Cai, M., and He, J. (2009). Diversity of microbial eukaryotes in Kongsfjorden, Svalbard. Hydrobiologia 636, 233-248.

Massana, R., Balagué, V., Guillou, L., and Pedrós-Alio, C. (2004). Picoeukaryotic diversity in an oligotrophic coastal site studied by molecular and culturing approaches. FEMS Microbiol. Ecol. $50,231-243$.

Melnikov, I. A. (1997). The Arctic Sea Ice Ecosystem. Amsterdam: Gordon and Breach Science Publishers.

Mock, T., and Thomas, D. N. (2005). Recent advances in sea-ice microbiology. Environ. Microbiol. 7, 605-619.

Montresor, M., Procaccini, G., and Stoecker, D. K. (1999). Polarella glacialis, gen. nov., sp. nov. (Dinophyceae): Suessiaceae are still alive! J. Phycol. 35, 186-197.

Moon-Van Der Staay, S. Y., De Wachter, R., and Vaulot, D. (2001). Oceanic $18 \mathrm{~S}$ rDNA sequences from picoplankton reveal unsuspected eukaryotic diversity. Nature 409, 607-610.

Moorthi, S., Caron, D. A., Gast, R. J., and Sanders, R. W. (2009). Mixotrophy: a widespread and important ecological strategy for planktonic and seaice nanoflagellates in the Ross Sea, Antarctica. Aquat. Microb. Ecol. 54, 269-277.

Moreira, D., and López-García, P. (2002). The molecular ecology of microbial eukaryotes unveils a hidden world. Trends Microbiol. 10, 31-38.

Moreira, D., and López-García, P. (2003). Are hydrothermal vents oases for parasitic protists? Trends Parasitol. 19, 556-558.

Myung, G., Yih, W., Kim, H. S., Park, J. S., and Cho, B. C. (2006). Ingestion of bacterial cells by the marine photosynthetic ciliate Myrionecta rubra. Aquat. Microb. Ecol. 44, 175-180.

Newell, S. Y. (1996). Established and potential impacts of eukaryotic mycelial decomposers in marine/terrestrial ecotones. J. Exp. Mar. Biol. Ecol. 200, 187-206.

Not, F., Gausling, R., Azam, F., Heidelberg, J.F., and Worden, A.Z. (2007). Vertical distribution of picoeukaryotic diversity in the Sargasso Sea. Environ. Microbiol. 9, 1233-1252.

Olli, K., Wassmann, P., Reigstad, M., Ratkova, T. N., Arashkevich, E., Pasternak, A., Matrai, P. A., Knulst, J., Tranvik, L., Klais, R., and Jacobsen, A. (2007). The fate of production in the central Arctic Ocean - top-down regulation by zooplankton expatriates? Prog. Oceanogr. 72, 84-113.

Palmisano, A. C., and Garrison, D. L. (1993). "Microorganisms in Antarctic sea ice," in Antarctic Microbiology, ed. E. I. Friedman (New York, NY: WileyLiss), 167-218.

Perovich, D. K., Andreas, E. L., Curry, J. A., Eiken, H., Fairall, C. W., Grenfell, T. C., Guest, P. S., Intrieri, J., Kadko, D., Lindsay, R. W., Mcphee, M. G., Morison, J., Moritz, R E., Paulson, C. A., Pegau, W. S., Persson, P. O. G., Pinkel, R., Richter, M. J. A., Stanton, T., Stern, H., Sturm, M., Tucker, W. B., and Uttal, T. (1999). Year on Ice Gives Climate Insights. Washington, DC: American Geophysical Union.

Philippe, H. (1993). MUST, a computer package of management utilities for sequences and trees. Nucleic Acids Res. 21, 5264-5272.

Piquet, A., Scheepens, J., Bolhuis, H., Wiencke, C., and Buma, A. (2010). Variability of protistan and bacterial communities in two Arctic fjords (Spitsbergen). Polar Biol. 33, 1521-1536.

Potvin, M., and Lovejoy, C. (2009). PCRbased diversity estimates of artificial and environmental 18S rRNA gene libraries. J. Eukaryot. Microbiol. 56, 174-181.

Richards, T. A., and Bass, D. (2005). Molecular screening of free-living microbial eukaryotes: diversity and distribution using a meta-analysis. Curr. Opin. Microbiol. 8, 240-252.

Richter-Menge, J. A., Perovich, D. K., Elder, B. C., Claffey, K., Rigor, I., and Ortmeyer, M. (2006). "Ice massbalance buoys: a tool for measuring and attributing changes in the thickness of the Arctic sea-ice cover," in Annals of Glaciology, eds P. Langhorne and V. Squire (Cambridge: International Glaciological Society), 205-210.

Romari, K., and Vaulot, D. (2004). Composition and temporal variability of picoeukaryote communities at a coastal site of the English Channel from $18 \mathrm{~S}$ rDNA sequences. Limnol. Oceanogr. 49, 784-798.

Sanders, R. W. (1991). Mixotrophic protists in marine and freshwater ecosystems. J. Eukaryot. Microbiol. 38, 76-81.

Schloss, P. D., Westcott, S. L., Ryabin, T., Hall, J. R., Hartmann, M., Hollister, E. B., Lesniewski, R. A., Oakley, B. B., Parks, D. H., Robinson, C. J., Sahl, J. W., Stres, B., Thallinger, G. G., Van Horn, D. J., and Weber, C. F. (2009). Introducing mothur: open-source, platform-independent, communitysupported software for describing and comparing microbial communities. Appl. Environ. Microbiol. 75, 7537-7541.

Sherr, E. B., and Sherr, B. F. (2007). Heterotrophic dinoflagellates: a significant component of microzooplankton biomass and major grazers of diatoms in the sea. Mar. Ecol. Prog. Ser. 352, 187-197.

Stoeck, T., Kasper, J., Bunge, J., Leslin, C., Ilyin, V., and Epstein, S. (2007). Protistan diversity in the Arctic: a case of paleoclimate shaping modern biodiversity? PLoS ONE 2, e728. doi: 10.1371/journal.pone.0000728

Terrado, R., Vincent, W. F., and Lovejoy, C. (2009). Mesopelagic protists: diversity and succession in a coastal Arctic ecosystem. Aquat. Microb. Ecol. 56, 25-40.

Thomas, D. N., Lara, R. J., Eicken, H., Kattner, G., and Skoog, A. (1995). Dissolved organic matter in Arctic multi-year sea ice during winter: major components and relationship to ice characteristics. Polar Biol. 15, 477-483.

Tian, F., Yu, Y., Chen, B., Li, H., Yao, Y.-F., and Guo, X.-K. (2009). Bacterial, archaeal and eukaryotic diversity in Arctic sediment as revealed by $16 \mathrm{~S}$ rRNA and 18S rRNA gene clone libraries analysis. Polar Biol. 32, 93-103.

Vaulot, D., Romari, K., and Not, F. (2002). Are autotrophs less diverse than heterotrophs in marine picoplankton? Trends Microbiol. 10, 266-267.

Werner, I., Ikävalko, J., and Schünemann, H. (2007). Sea-ice algae in Arctic pack ice during late winter. Polar Biol. 30, 1493-1504.

Wu, Z., Tsumura, Y., Blomquist, G., and Wang, X. R. (2003). 18S rRNA gene variation among common airborne fungi, and development of specific oligonucleotide probes for the detection of fungal isolates. Appl. Environ. Microbiol. 69, 5389-5397.

Yoo, Y. D., Jeong, H. J., Kim, M. S., Kang, N. S., Song, J. Y., Shin, W., Kim, K. Y., and Lee, K. (2009). Feeding by phototrophic red-tide dinoflagellates on the ubiquitous marine diatom Skeletonema costatum. J. Eukaryot. Microbiol. 56, 413-420.

Conflict of Interest Statement: The authors declare that the research was conducted in the absence of any commercial or financial relationships that could be construed as a potential conflict of interest.

Received:01 March 2011; accepted:28 April 2011; published online: 11 May 2011.

Citation: Bachy C, López-García P, Vereshchaka A and Moreira D (2011) Diversity and vertical distribution of microbial eukaryotes in the snow, sea ice and seawater near the North Pole at the end of the polar night. Front. Microbio. 2:106. doi: 10.3389/fmicb.2011.00106

This article was submitted to Frontiers in Extreme Microbiology, a specialty of Frontiers in Microbiology.

Copyright $\odot 2011$ Bachy, López-García, Vereshchaka and Moreira. This is an openaccess article subject to a non-exclusive license between the authors and Frontiers Media SA, which permits use, distribution and reproduction in other forums, provided the original authors and source are credited and other Frontiers conditions are complied with. 